\title{
THE CONCEPT OF THE IMAGO DEI: COHERENCE WITH EVOLUTIONARY SCIENCE?
}

\author{
Annette Evans \\ Postgraduate School \\ University of the Free State
}

\begin{abstract}
Gen 1:26-27 has traditionally been interpreted as implying that humankind was uniquely created in the image of God. However, cumulative scientific developments following on Darwin's theory of evolution have conclusively proved the evolutionary and genetic continuity between more ancient forms of life and homo sapiens sapiens. Wentzel van Huyssteen poses the question whether the "heart of the tradition" of the imago Dei can be recovered and revisioned? This article considers firstly what the image of God of the original author of Gen 1:2627 was, and secondly whether such a concept could be coherent with our current scientific knowledge. To address the first question, the exegesis as understood by an author who lived as close as possible to the time of origin of the text, viz. Philo of Alexandria, is examined. The second question is approached by means of the post-foundationalist interdisciplinary epistemology as advocated by Van Huyssteen.
\end{abstract}

Key words: Imago Dei; Gen 1:26-27; Philo of Alexandria; post-foundationalist epistemology; evolutionary science; Wentzel van Huyssteen; John de Gruchy

\section{Introduction}

Looking back over the history of Christian faith and theology, one thing is clear: nothing was ever gained by Christians' denial of our growing knowledge about the natural world (Grant 1998:46).

Theology has traditionally ignored the crucial developments in the field of science (Bowker 1970:290). ${ }^{1}$ The iconic imago Dei text Gen 1:26-27 “... So God created humankind in his image ..." has been understood in many different ways, but in general the belief that there is a definite difference in essential being between humans and animals, has been taken for granted (De Gruchy 2013:109). Yet, as seen in a variety of other recent scientific disciplines, human cognition evolved from earlier forms of life, and thus the fundamental assumption of Christian theology that there is a radical split between human beings and other living species, must be reconsidered. ${ }^{2}$ Van Huyssteen (2006:106-08, 307, 311, 314) confronts the implications for the doctrine of the imago

"For all religions ... the exploration of the principle of coherence is perhaps the most urgent task before us in the attempt to understand the relationship ... between religious and secular accounts of existence" (Bowker 1970:290). Also see Van Rooyen (2016:1); Du Rand (2013:291-93).

2 Notably, the Apostles', Nicene, and Athanasius Creeds make no mention of the imago Dei. 
Dei when he poses the question whether there is any way that "the heart of the Christian tradition of the imago Dei can be recovered and revisioned" through an interdisciplinary dialogue with current scientific views on human uniqueness. He (1999:284-85) suggests that a post-foundationalist Christian theology is needed, in which the focus must be on "a relentless criticism of our uncritically held crypto-foundationalist assumptions". What image of God did the author have in mind when he stated "Let us make humankind in our image, according to our likeness" at a time when it was generally believed that the world was flat and had four corners, and the Creator was a patriarchal figure who demanded absolute obedience?

Hurtado (1988:128) points out that in studying ancient religious texts it is necessary to "first appreciate the religious life that preceded and underlay the ancient development". In order to understand Gen 1:26-27 within its own time-frame, cognisance must be taken of the "entirely different sensibility about the meaning of meaning from the logocentric one that drives Western thought" (Boyarin 2000:171). ${ }^{3}$ In view of the fact that we now know that humankind evolved from simpler forms of life, is there really a distinctive characteristic that the Deity shares with humankind and not with animals? In seeking coherence, this article poses the corollary of Van Huyssteen's question of whether the imago Dei can be recovered, viz. in what way could the human subspecies Homo sapiens sapiens be carrying the image of God today? ${ }^{4}$

\section{Methodology}

This article explores the possibility of an understanding of the original author's use of the terms "image" and "likeness" that have the potential to be coherent with our current scientific knowledge. The question of how theology and science should relate to one another is an epistemological issue (Gregersen 2015:141-159). Gericke (2013:212, 223) raises the underlying axiological difficulties of the unspecified assumptions in Genesis 1. ${ }^{5}$ Van Huyssteen (in Gregerson 2015:151) acknowledges science as the prime case for the cognitive pursuit of truth, but insists that scientific rationality is just one subset of rationality at work. He makes a plea for rationality and nonfoundationalism in theology. Van Huyssteen (1999:284-85) suggests that theologians must be "freed from being the fideistic prisoners of our preferred traditions and respective disciplines" and be enabled to "discover the shared epistemic resources as well as the interdisciplinary ability for critically evaluating our problem-solving traditions". Theological statements rest on a fluid network of religious metaphors and models which have an explorative nature (Van Huyssteen 1998:61; Barbour 1997:159-157). Van Huyssteen (2006:307) considers that the traditional Christian understanding of the imago Dei as uniquely human can be explored in the light of recent scientific research on the origins of humankind by means of interdisciplinary dialogue. But he makes the proviso that for genuine interdisciplinary

See Evans (2007:9) for a definition of Derrida's concept of Western “logocentrism".

See Fuentes 2017:46-47, 100.

When we confront the question of exactly what image and likeness humankind, as opposed to animals, was made in, the only information we are given in the text about the pattern, the original Elohim, is that Elohim is the "creator" of heaven and earth, that Elohim "said", "saw", "called/named", and that Elohim axiomatically assessed what Elohim created as "good". Therefore, in order to divine what is meant by these properties describing the "image and likeness" that were bestowed on humankind, the only model we have is these characteristics of Elohim. 
conversation to transpire, it is "essential to move beyond the kind of fideism where our own unique experiences and appropriate explanations are never challenged" (1999:34, 284-85). He claims (in Gregersen 2015:151) that rationality can emerge in the crossing over or interweaving of forms of rational discernment in different areas of life in an openended transversality.

In this enquiry Van Huyssteen's post-foundationalist interdisciplinary theological approach is applied. ${ }^{6}$ In order to consider relevant new scientific discoveries from a religious point of view, he explains his programme of "postfoundationalist theology" as follows:

Precisely by allowing ourselves to freely and critically explore the experiential and interpretive roots of all our beliefs in our various domains of knowledge, we as theologians too are freed to speak ... from within a personal faith commitment, and in this cross-disciplinary conversation with those of other traditions and other disciplines, to discover patterns that may be consonant with or complementary to the Christian worldview (Van Huyssteen 1999:284-85).

The research question requires both a contemporary concept of what God could be like and an understanding of what the original author had in mind when he used the term "image of God". In order to consider the latter question, the earliest available exegetical text that is closest in time to the original biblical text is used as a foundation. Therefore, the exegesis of this concept in Genesis by Philo of Alexandria is presented. It is helpful that Philo was a Hellenistic Jew and wrote in Greek because the language provides some coherence with the Hellenistic influences on the early Christian church fathers and subsequent theologians who have wrestled with this question in relation to the Greek New Testament. Currently there are basically four theological understandings of the concept of the imago Dei. These have been summarised by other scholars, and will not be dealt with directly in this article. ${ }^{7}$ This article is focused mainly on the possibility of a degree of coherence of Philo's understanding with relevant scientific discoveries in our current postmodern theological context. To this end the work of De Gruchy (2013) is referred to in considering the research question.

\section{The exegesis of Gen 1:26-27 by Philo of Alexandria (ca. 30 BCE - 50 CE)}

Philo of Alexandria was an intellectually sophisticated Hellenistic Jew who interpreted the account of the creation of humankind in Genesis 1 and 2 in terms of Greek philosophy. The text closest to what Philo probably used, is the LXX:

Then God said, "Let us make humankind in our image, according to our likeness;" So God created humankind in his image, in the image of God he created them (NRSC)

\footnotetext{
6 Van Huyssteen brought the problem to the fore in 2006 with his ground-breaking book Alone in the World, but his earlier works also contribute to the methodological approach of this article.

7 For instance, Simango (2016:6-8) notes the wide range of opinions on the imago Dei in the modern period, from functional or substantive (in connection with Christ) to the relationship view, or a combination of the variables.
} 


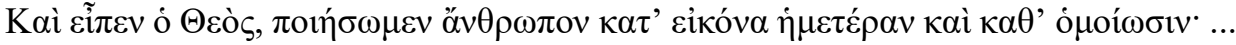

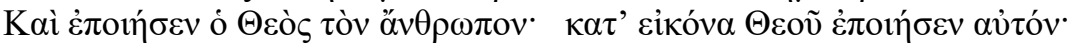

....

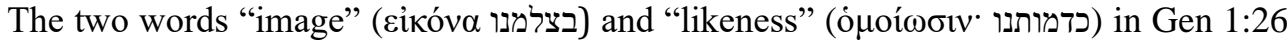
are not synonyms. The word "likeness" serves a qualifying function in terms of the "image", but is not repeated in verse 27 . The foundational assumption of this enquiry is that the polysemous character of these words "image" and "likeness" implies that the resemblance of humanity to God in terms of "image" and "likeness" should not be taken literally. ${ }^{8}$ The word "likeness" does not specify in what aspect the resemblance lies. The Oxford English Dictionary states that "image" can mean "An artificial imitation of the external form of an object", but interestingly, it is the source of the word "imagination" - "the creative faculty of the mind/mental faculty forming images of external objects not present to the senses". This contemporary definition of "image" is surprisingly harmonious with Philo's abstract understanding of the term: in De Opificio Mundi he explains that the human being after the sikóvo image (Gen 1:27) is an abstract,

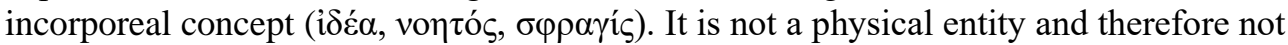
differentiated as male or female, and only perceivable by the mind. He specifies that it is immortal.

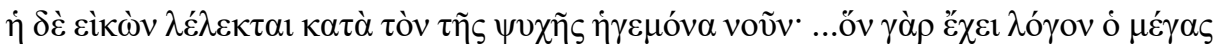

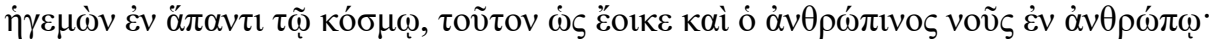

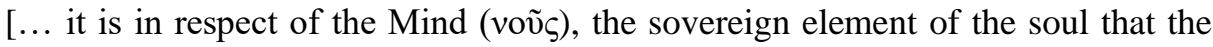
word "image" is used; ... for the human mind (ó $\alpha v \theta \rho \omega ́ \pi ı v o \varsigma$ voṽ $\varsigma$ ) evidently occupies a position in men precisely answering to that which the great Ruler (o

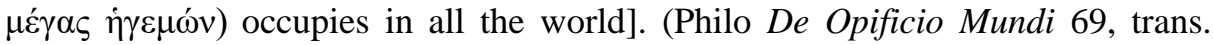
Colson and Whitaker 1929:55).

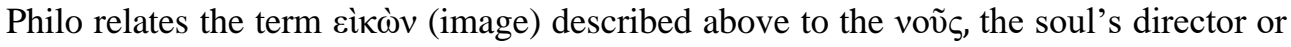
intellect, which he equates with the Logos. It is this quality which gives humankind the ability to claim an image relation to God - God has bestowed his own intellect upon humankind in the form of the $\alpha \dot{\alpha} \theta \rho \omega ́ \pi \mathrm{v} o \varsigma$ voṽ $\varsigma$, the human mind (Runia 2001:235). Philo equates the creative power through which God frames the world as the Logos - the active element of God's creative thought. He explains his reasoning in Quest in Gen II.62:

For nothing mortal can be made in the likeness of the most high One and Father of the universe but [only] in that of the second God, who is His Logos ( $\pi \rho$ ò $\varsigma$ òv

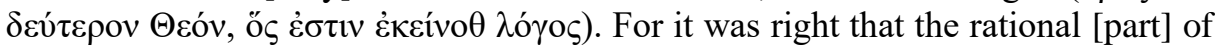
the human soul should be formed as an impression by the divine Logos, since the

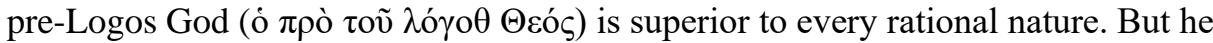
who is above the Logos [and] exists in the best and in a special form - what thing that comes into being can rightfully bear His likeness? (Colson and Whitaker 1929) 
Thus, for Philo the divine reason-principle (Logos) is the active element of God's creative thought (Isaacs 1992:197). Hence, the sense in which man bears the image of God is that humankind possesses the ability to think and act creatively, derived from the "rational" Logos, which is the instrument of God in the creation of the world. According to Philo it is in the "divine reason principle" that humankind's imago Dei resides. ${ }^{9}$

\section{Gen 1:26-27 in the current postmodern global context}

Drummond (in Kennedy 1953:67) recognised more than 150 years ago in Britain that although the Bible lends itself to revelation, "theology is only beginning to realize how radical is the change in mental attitude of those who have learned to think from science". Only a few years after Galileo (1564-1642) came into conflict with the dominant Christian church as a result of his discovery of the laws of planetary motion, Descartes' (1596-1650) dualistic view of the world and human beings made a crucial difference in epistemology. His philosophy theoretically separated science and theology into two radically different spheres, and facilitated the reception of new knowledge about nature and history. Newton's (1642-1727) discovery of the law of gravity and hypothesis of the ordered structure of the universe radically changed the earlier biblical understanding of the physical structure of the world. Einstein's important theory of relativity in the early $20^{\text {th }}$ century brought new scientific insight, but the crucial breakthrough was prior to that in the $19^{\text {th }}$ century, when Darwin proved that natural selection was the driving force of the evolution of all living species. This radical paradigm shift, with which fundamentalist religious groups still experience difficulty, "relegated humans from being exceptional or fundamentally different from the rest of nature and placed us firmly within the evolving animal kingdom" (De Gruchy 2013:108). Incontestable confirmation came in the mid$20^{\text {th }}$ century when Franklin, Crick and Watson discovered that DNA, the "mysterious ghost of life", is visible, computable, and different for every form of life, and even every single human being (De Gruchy 2013:109).

Another challenge to foundationalism was the advent of modern biblical and textual criticism. It is based largely on the recognition that the "Spirit-given text" was given to us by and through human authors. Without taking cognisance of the cultural-contextual background of the text, biblical exegetes are vulnerable to the possibility of rhetoric employed to convey a biased ideology (Brueggemann et al. 2002:20, 21). ${ }^{10}$ The consequent exploration of contextual and ideological motivations of Scripture have exposed possible epistemological problems for religious faith. But while theology was still catching up with the modern way of thinking about theological problems, postmodernity dawned, and revealed the limitations of reason. De Gruchy (2013:113-14) defines post-modernity as

paradigm shifts in science that have undermined previously held certainties, by global multiculturalism, challenges to entrenched power-relations, traditional understandings of human sexuality, discrimination against 'the other', moral and

\footnotetext{
9 In his summary of the history of interpretation of the imago Dei from Philo's time to the present, Simango (2016:2) recognises that the church fathers Irenaeus, Augustine and Aquinas, like Philo, were influenced by Greek philosophy and understood the image of God in humankind as the power of reason. 
philosophical relativism and by late capitalism ... the attempt to understand and critically evaluate modernity from within this post-modern framework. It emphasizes respect for difference, rejects meta-narratives and hierarchies, challenges patriarchy, anthropocentrism and destructive power-relations along with global cultural and economic hegemonies, and is sceptical of dogmatic truth claims.

As new data emerges, conceptual frameworks must evolve. Today, in our postpostmodern context, we have come full circle; empiricism as a way of knowing in the post-modern context is no longer dominant. De Gruchy (2013:110) poses the age-old question: "How then can we know God?"

To explore this question, he details the stages through which the traditional understanding of the imago Dei developed. According to Gen 2:7 that which gives animals, including humankind, vitality or life, is nephesh 2 . De Gruchy notes that the Hebrew word nephesh is always embodied in basar (flesh); without nephesh the flesh has no life. In LXX Gen 2:7, when God breathes into man's face, the Hebrew word

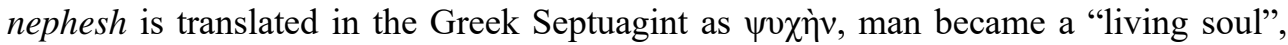

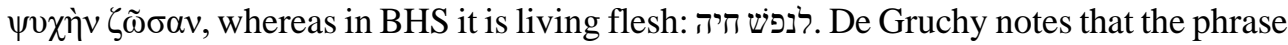
in BHS "living being" captures well the Hebrew holistic understanding of human beings as bodies animated by spirit, but he ignores the clear indication in Gen 1:21 that this text

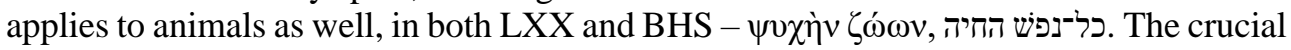
problem is that the Platonic concept of "soul" crept in as a result of the Septuagint's use

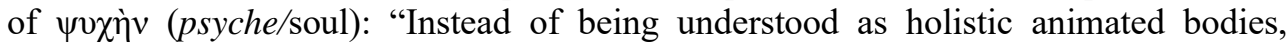
humans are understood as embodied immortal souls" (De Gruchy 2013:152-53). Van Huyssteen (2006:262) defines the imago Dei as "embodied human uniqueness". Yet, in terms of the original Hebrew terminology, both animals and humankind are simply "living beings" (as in Gen 1:21), and both are "blessed" by Elohim to be fruitful and multiply (Gen 1:21 and Gen 1:28).

De Gruchy (2013:153, 172-73) falls back on the traditional Christian dualistic Greek philosophical concept that humankind has a soul which is distinct from the body. By referring to the meta-text Gen 3:22: "Then the Lord God said, 'See, the man has become like one of us, knowing good and evil"' he (2013:152-53) relates the imago Dei text to the "Fall" and reverts to the assumption of a radical difference between humans and animals. Thus, De Gruchy (2013:152) also accepts the Hellenistic influence and interprets Gen 3:22 as "the emergence of an embodied moral awareness, and a holistic, new way of knowing".

\section{The question of progress in evolution}

Drummond (in Kennedy, 1953:78) understands Darwin's original view to be that nature evolved with a definite purpose: the final goal of man as a moral creature. He believes that "scientific theology is giving us a Bible with a new exegesis, a reconsideration of the historic setting, and a clearer view of the moral purposes of God, [which] would change from barriers into bulwarks of the faith". Like Drummond and De Gruchy, Bentley (2018:6) too, in his critique of the concept of the imago Dei, cannot evade the belief that the processes of life are geared towards progress. He suggests that a viable alternative to the traditional concept of the imago Dei is that "there is something special about participating as human beings in the progress and processes of life". The problem 
is that the idea of evolution as possessing directional development is incompatible with the mainstream scientific view. Foremost evolutionary scientists who work within the framework of "Modern Synthesis" insist that evolution has no directionality; the process of evolution is random and cannot be seen as development towards progress. According to them, evolutionary changes are brought about by random mutation and natural selection, which are incompatible with the idea of progress or purpose. ${ }^{11}$

However, recently Laland et al. (2015:6) claim that "the burden of creativity in evolution (i.e. the generation of adaptation)" does not rest on random natural selection alone. They propose an alternative conceptual framework: the "extended evolutionary synthesis" (EES). While retaining the fundamentals of evolutionary theory, they emphasise the role of reciprocal constructive processes in development and evolution. Thus, they claim that developmental processes which operate through reciprocal portrayals of causation and developmental bias such as niche construction, do in fact determine the direction and rate of evolution. The implication that developmental plasticity is capable of introducing phenotype novelty when the organism embarks upon niche construction implies that repeated evolution in isolated populations may be due to convergent selection and/or developmental bias. This concept has been confirmed by the Cambridge paleoanthropologist Simon Conway Morris in his research on the biological evolution of consciousness. He $(2016: 300,310)$ presents a vast array of examples in nature of how evolution reinvents itself time and time again in the same way by means of "convergent evolution". The implication is that evolutionary outcomes are to some extent limited, and thus the process of evolution is far from random. He concludes that "somehow consciousness is emergent". By implication, this process is not only intrinsically creative, but indeed progressive and purposeful.

Another recent challenge to the random element of "classic" Modern Synthesis is presented by Fuentes (2017). In line with the research of Laland et al. and in harmony with the recent development of epigenetics, he describes a recently identified brain gene unique to humans that evolved some 37,000 years ago and is now found in 70 per cent of the population. ${ }^{12}$ Fuentes reasons that the changes in brain genes developed as a result of human cultural adaptation. He (2017:292) maintains that "Being human is a creative process".

\section{Discussion}

The question now is: is it possible that Philo's idea of "rationality" as that uniquely creative human ability bestowed by the Logos, in combination with scientific evidence of Laland's "phenotype plasticity", can be brought into coherence with the idea of progressive evolution toward achieving some semblance of the imago Dei in terms of rationality? Coyne (2009:253) reminds us: "We are the one creature to whom natural selection has bequeathed a brain complex enough to comprehend the laws that govern the universe ... the only species that has figured out how we came to be." Although the

\footnotetext{
11 See Evans (2013:315-33) for an earlier discussion of epistemological implications of these aspects for Christianity.

1237000 years ago a dramatic creative explosion took place - cave art emerged, and modern humans began to spread across Europe, leaving evidence of flourishing civilisations. A second brain gene that is unique to humans and developed some 6000 years ago, is now present in 60 per cent of the population.
} 
eventual evolution of technologies such as the use of fire for cooking, stone tool-making and language would have contributed to an increase in brain size and consequently cognition, and thus consciousness, Van Huyssteen (2006:311) insists that "that does not mean that the theory of evolution by natural selection can offer an adequate explanation for beliefs that far transcend their biological origins". ${ }^{13}$ This claim is supported by several theologians and scientists. For instance, Ferguson (2014:88) supports the idea of progress with his recognition of "the extent to which suffering, waste, and the competition for survival appeared to be the drivers of evolution". He notes that Darwinism "showed the Bible and the Christian tradition capable of providing resources for dealing with a new set of problems". De Gruchy (2013:172-73) defines the imago Dei as follows:

[It] refers to the mystery of our being, fragments, if you like, of a much larger, cosmic mystery we call God. Central to that understanding of being human is the notion of soul, a complex embodied reality, which gives continuity to our identity as persons in relation to others, a 'sacred space' which gives us dignity and in turn provides a basis for moral responsibility, human rights and respect ... it has to do with us in relationship to one another (De Gruchy 2013:172-73).

Van Huyssteen (2006:119-244) extrapolates the realisation of eschatological responsibility to the ability to "be in discourse with God and to be connected to one another in caring relationships, also to our "sister species". For instance, the globalism that has developed as a result of evolutionary progress has enabled the Tibetan Buddhist Dalai Lama and South African Anglican Bishop Tutu to collaborate in a true "postfoundationalist theological crossing over, to jointly arrive at the conclusion that the only way to change the world is through teaching compassion ... the basic human values, the inner values that lie at the heart of who we are as humans" (Dalai Lama in Abrams 2016:269-70). Conway Morris (2016:299) concludes: "Our inability to provide any adequate explanation for the nature of consciousness indicates that we are dealing with unfinished business ... we need to move beyond evolution" ${ }^{14}$ In this respect Elizabeth Johnson (2017) extends the need for compassion to all manifestations of life based on the inter-dependence and relationality of all of creation. Yet, the immediate reality of dire poverty and starvation confronts us. After Johnson's talk a highly relevant comment was made by an African member of the audience who pointed out that in some instances the natural environment is being devastated precisely because of the immediate need for human survival in the face of starvation.

\section{Conclusion}

Modern humans appear to have progressed in respect of applying reason to think rationally and act creatively, yet Van Huyssteen (in Gregerson 2015:157) recognises that

13 Van Huyssteen (2006:311) claims that human cognition also entails a drive for metaphysical explanation, including notions of another world and life after death.

14 Conway Morris (2016:290, 299) affirms that as a product of evolution the differences that separate us humans from certain animals are paper thin, but he asks whether this is true of the mind, which, like Philo, he calls "rationality". He points out that the ability to see, so clearly convergent in its evolution, is not the same as "thinking". 
in the paleoanthropological record early humans already showed signs of symbolic awareness, a trait which he associates with self-reflection..$^{15}$ Van Huyssteen (2006:314) notes that "it is precisely evolutionary epistemology's focus on the evolution of human cognition that revealed embodied human cognition as the mediator between biology and culture". Could self-reflection be the ability to reason that Philo identifies in Gen 1:2627 as the "image" of the divine Creator? Could this be manifested in humans as a striving to attain a "likeness" to the consciousness of God? Is God's image simply a nondimensional spiritual consciousness, and as such a creative power? If it is, then it could well entail care and love, i.e. compassion. Van Huyssteen's approach to the problem by viewing it as eschatological - the imago Dei as "a task waiting to be realized for any human being" - harmonises with Conway Morris's concept of "unfinished business", and perhaps even with Fuentes' proposition that human cultural adaptation implies that we are building our own evolutionary future. If evolution as natural selection is a progressive process, then this creative aspect of the imago Dei is a developmental plasticity task waiting to be realised by the church too.

\section{BIBLIOGRAPHY}

Abrams, D, in consultation with His Holiness the Dalai Lama and Bishop Desmond Tutu. 2016. The book of joy. Lasting happiness in a changing world. London: Hutchinson.

Barbour, IG. 1997. Religion and science: Historical and contemporary issues. London: SCM.

Bentley, W. 2017. Are we special? A critique of Imago Dei, HTS 73/3. Online: http://dx.doi.org/10.4102/hts.v7313.4524. Accessed 10 Oct 2018.

Bowker, J. 1970. Problems of suffering in religions of the world. London/New York: Cambridge University Press.

Brueggemann, W, Placher, WC, and Blount, BK. 2002. Struggling with Scripture. Louisville, Kentucky: Westminster John Knox Press.

Boyarin, D. 2000. Midrash, in AKM Adam (Ed.) Handbook of postmodern Biblical interpretation. St Louis, Missouri: Chalice Press, 167-174.

Clines, DJA. 1995. A world established on water (Psalm 24): Reader-response, deconstruction and bespoken interpretation. In DJA Clines, Interested parties: the ideology of writers and readers of the Hebrew Bible, JSOT Sup 205. Sheffield: Sheffield Academic Press, 172-186.

Colson, FH and Whitaker, GH (Translators). 1929. Philo I-V. Loeb Classical Library. London/Cambridge, Mass.: Harvard University Press.

Conway Morris, S. 2016. The runes of evolution. How humankind became self-aware. Cambridge: Cambridge University Press.

Coyne, JA. 2009. Why evolution is true. Oxford: Oxford University Press.

15 He finds evidence for this in Neolithic archaeological sites which are replete with deliberate burial sites, implying a religious imagination which reflects belief in an afterlife. The discovery of Homo Naledi in 2013 in the "Cradle of Mankind" again reminded us how recent in the history of the world is the evolution of technologies and language. 
De Gruchy, JW. 2013. Led into mystery. Faith seeking answers in life and death. London: SCM Press.

Du Rand, J. 2013. Evolusie, wetenskap en geloof. ' $n$ Biografiese inleiding tot die denke van Teilhard de Chardin. Wellington: BM Bybel-Media.

Evans, AHM. 2007. The development of Jewish beliefs in angels: Egyptian and Hellenistic connections ca. 600 BCE - 2000 CE. Unpublished DPhil dissertation, Stellenbosch University.

Evans, AHM. 2013. Interpreting the Bible for children in coherence with evolution, OTE 26/2 (2013):315-333.

Ferguson, D. 2014. Creation: Guides to Theology. Grand Rapids, Michigan/Kentucky, UK: Wm B Eerdmans.

Fuentes, A. 2017. The creative spark. How imagination made humans exceptional. New York: Dutton.

Gericke, J. 2013. A philosophical clarification of the axiological assumption behind the concept of goodness in Genesis 1, Journal for Semitics 22/1:210-225.

Grant, CD. 1998. Thinking through our faith. Theology for $21^{\text {st }}$ century Christians. Abingdon Press.

Gregersen, NH. 2015. J. Wentzel van Huyssteen: Exploring venues for an interdisciplinary Theology, Theology Today, Vol. 72(2):141-159.

Haught, JF. 2008. God after Darwin: A Theology of evolution. Boulder: Westview Press.

Hurtado, LW. 1988. One God, One Lord. Philadelphia: Fortress.

Isaacs, ME. 1992. Sacred space. An approach to the Theology of the Epistle to the Hebrews. Sheffield: Sheffield Academic Press.

Johnson, Elizabeth. 2017. Ask the beasts. Spirituality and the evolving earth, Evelyn Underhill Annual Lecture, Boston College of Theology and Ministry, 13 July 2017. Online: https://www.youtube.com. Accessed 8 Oct 2019.

Kennedy, JW (Ed.). 1953. Henry Drummond. An anthology. New York: Harper \& Collins.

Laland, KN, Uller, T, Feldman, MW, Sterelny, K, Muller, GB, Moczek, A, Jablonka, E and Odling-Smee, J. 2015. The extended evolutionary synthesis: its structure, assumptions and predictions, Proc. $R$, Soc. B 282: 2015.1019. Online: http:dx.doi.org/10.1098/rspb.2015.1019. Accessed 12 July 2019.

Middleton, RJ. 2005. The liberating image, the Imago Dei in Gen 1. Grand Rapids, Michigan: Brazers Press.

Runia, DT. 2001. Philo of Alexandria. On the creation of the cosmos according to Moses. Introduction, translation and commentary. Leiden: Brill.

Simango, D. 2016. The Imago Dei (Gen 1:26-27): A history of interpretation from Philo to the present, Studia Historiae Ecclesiasticae 42/1. Online: http://dx,doi.org/10.17159/2412-4265/2016/1065. Accessed 10 Oct 2018.

Van Huyssteen, W. 1999. The shaping of rationality, Towards interdisciplinarity in Theology and science. New Haven, Mi: Yale University Press.

Van Huyssteen, W. 2006. Alone in the world? Human uniqueness in science and Theology. 2004. The Gifford Lectures. Grand Rapids, Michigan: William B Eerdmans Publishing Company. 
Van Rooyen, JA. 2016. Why religious human beings need evolutionary epistemology! A theological and evolutionary viewpoint of why humans need to embrace evolutionary epistemology, Verbum et Ecclesia 37/1 (2016), a 1476. Online: http.//dx.doi.org/10.4102/ve.v37i1.1476.7. Accessed 12 March 2017. 